\title{
Investigation of volatile organic compounds in the cabin air of new cars
}

\begin{abstract}
Potential human health effects of material emissions in new car cabins are of great public concern. In present work, four new cars with different equipment were tested to assess the nature of volatile organic compounds (VOCs) associated with new vehicle interior. Air samples were collected on solid sorbents and analyzed using thermal desorption and GCMS/FID. Different types of sorbents were applied to effectively adsorb VOCs. The maximal number of VOCs, trapped from the in-vehicle air, was identified and compounds occurring in air from cabins of all examined vehicles were selected and classified. VOCs emission from identified compounds was calculated and potential sources of identified VOCs were discussed. For aromatic hydrocarbons, the comparison of individual VOCs concentrations was performed.
\end{abstract}

Key words: $V O C$, new car, vehicles interior, indoor air pollution

\section{Badanie lotnych związków organicznych występujących w powietrzu z wnętrza kabin nowych samochodów}

\begin{abstract}
Potencjalny wpływ na ludzkie zdrowie wywierany przez emisję zwiazków z materiałów występujacych w kabinach nowych samochodów jest tematem wywohującym wiele emocji. W niniejszej pracy zbadano cztery nowe samochody z różnym wyposażeniem $w$ celu określenia charakteru lotnych zwiazków organicznych (LZO) pochodzacych $z$ wnętrza nowych pojazdów. Próbki powietrza pobierano na adsorbenty state i analizowano z wykorzystaniem techniki desorpcji termicznej sprzężonej z GC-MS/FID. Zastosowano różne typy adsorbentów celem efektywnej adsorpcji LZO. Zidentyfikowano maksymalna liczbę LZO pobranych z powietrza wewnątrz samochodu, a także wyodrębniono i sklasyfikowano zwiazki występujace w kabinach wszystkich badanych pojazdów. Wyznaczono emisję pochodzaca od zidentyfikowanych LZO oraz przeprowadzono dyskusję potencjalnych źródet pochodzenia zidentyfikowanych związów. Dla węglowodorów aromatycznych porównano stężenia poszczególnych zidentyfikowanych związków.
\end{abstract}

Słowa kluczowe: LZO, nowy samochód, wnętrze pojazdu, zanieczyszczenie powietrza wewnętrznego

\section{Introduction}

In recent years, greatly increased attention has been focused on the quality of indoor air. In the modern motorized society, people spend appreciable amount of time in automobiles, which present a unique indoor environment, therefore the air quality in car-cabin should be drawing attention from the same standpoints as on the indoor air quality in buildings and houses. Passengers travelling in vehicles are exposed to variety of organic pollutants, which may have significant effects on their health and comfort. Additionally, airborne pollutants in new car cabins are responsible for a "new car odor". To many, this odor is considered to be pleasant, but to some car users may be a strong nuisance and at high concentration may evoke sensory irritation.

According to the World Health Organization (WHO) [1], organic indoor pollutants, sampled by adsorption onto solid sorbents, have been classified into four groups concerning their boiling-point ranges: very volatile organic compounds (VVOC) with a boiling point range from $0{ }^{\circ} \mathrm{C}$ to $50-100$ ${ }^{\circ} \mathrm{C}$, volatile organic compounds (VOC): $50-100{ }^{\circ} \mathrm{C}$ to 240 $-260^{\circ} \mathrm{C}$, semivolatile organic compounds (SVOC): $240-$ $260^{\circ} \mathrm{C}$ to $380-400^{\circ} \mathrm{C}$ and organic compounds associated with particulate matter or particulate organic matter (POM): $>380{ }^{\circ} \mathrm{C}$. The other divisions can be made according to

\section{Wprowadzenie}

Obecnie szczególnie dużą uwagę skupia się na jakości powietrza wewnętrznego. W nowoczesnym społeczeństwie zmotoryzowanym ludzie spędzają znaczną ilość czasu w samochodach, będących szczególnym przypadkiem środowiska wewnętrznego, co powoduje, że jakość powietrza w kabinach samochodowych powinna stać się przedmiotem zainteresowania na równi z jakością powietrza wewnątrz budynków i domów mieszkalnych. Pasażerowie podróżujący samochodami narażeni są na różnego typu zanieczyszczenia organiczne, mogące mieć znaczący wpływ na ich zdrowie i komfort podróżowania. Dodatkowo zanieczyszczenia występujące w kabinach nowych samochodów odpowiedzialne są za tak zwany zapach nowego samochodu. Przez wiele osób zapach ten odczuwany jest jako przyjemny, ale dla niektórych użytkowników samochodów może być bardzo uciążliwy, a przy wysokich stężeniach wręcz wywoływać podrażnienie narządów zmysłów.

Według Światowej Organizacji Zdrowia (WHO) [1], organiczne zanieczyszczenia wewnętrzne, pobierane drogą adsorpcji na sorbentach stałych, zostały podzielone na cztery grupy ze względu na ich temperatury wrzenia: bardzo lotne związki organiczne (VVOC) z zakresem temperatur wrzenia od $0{ }^{\circ} \mathrm{C}$ do $50-100{ }^{\circ} \mathrm{C}$, lotne związki organiczne (VOC): $50-100^{\circ} \mathrm{C}$ do $240-260{ }^{\circ} \mathrm{C}$, średniolotne związki 
the chemical character of organic chemicals (alkanes, aromatic hydrocarbons, aldehydes, alcohols, etc.) or their potential health effect (irritants, neurotoxics, carcinogens, etc.) [2].

Odor in a new car cabin is caused by a complex mixture of various compounds emitted from interior parts and materials. VOCs associated with in-vehicle trim material emissions include the emission from sealants, carpets, plastic molding, adhesives, paints, leather and foam cushions. Other sources of interior vehicle VOCs might be cleaning substances, deodorisers, refreshers or lubricants, tobacco smoke and even microbial VOC emission $[3,4,5,6,7]$. The car cabin interior is very specific environment, due to the much higher than in average room ratio of the volume of interior materials to the indoor space. Furthermore, during summer, the temperature inside cabin easily arises, resulting in increased VOCs diffusion and much higher concentrations of chemicals than in residences. Depending on the component, humidity may also greatly affect the diffusion of VOCs. Generally, the diffusion behaviours of interior trim material VOCs could be classified into two types. The first one is associated with solvents used for paint materials and adhesives. Those compounds vaporize rapidly and are called vaporization rate controlled components. The second type can be found in additives and unreacted components. In case of those compounds, called diffusion rate controlled components, the diffusion process takes place in the extended period of time $[7,8]$.

Information about the type and concentration of chemical compounds diffusing from interior vehicle materials is extremely important for evaluating the health effects of human exposure, however little is known about this type of indoor air pollution in car cabins. Brown and Cheng [9] indicated that the main pollutants found in the new cars were benzene, acetone, ethylbenzene, xylene isomers, toluene and hydrocarbons. Most of them are toxic and are potential sources of health hazards, for example xylenes are fetal development toxic agents, aceton is a mucosal irritant, benzene is a known human carcinogen, while ethylbenzene is classified as potential human carcinogens by the International Agency for Research and Cancer [10]. Grabbs et al. [4] found over 60 VOCs inside the interiors of the four new vehicles, with total VOC concentrations generally exceeding those in ambient air and highly variable between examined cars. Only four compounds were identified in all vehicles: toluene, ethylbenzene, xylenes and undecane. Overton and Manura [11] investigated one new car to determine the presence and changes of VOCs over time. More than 100 of VOCs were identified with many straight and branched chain hydrocarbons, siloxanes, styrene, substituted benzenes, butylated hydroxytoluene (BHT), aldehydes and others. The obtained results suggest than VOC emissions decrease in a new car with time and are strongly temperature dependent. In Yoshida and Matsunaga study [7] as many as 162 organic compounds, involving many aliphatic and aromatic hydrocarbons, were identified in the interior air of a one new car. Total VOC organiczne (SVOC): $240-260^{\circ} \mathrm{C}$ do $380-400^{\circ} \mathrm{C}$ oraz pyły i aerozole organiczne $\mathrm{z}$ temperaturami wrzenia $>380{ }^{\circ} \mathrm{C}$. Można dokonać również innych podziałów, np. na podstawie charakteru chemicznego związków (alkany, węglowodory aromatyczne, aldehydy, ketony itp.), bądź ich potencjalnego wpływu na zdrowie ludzkie (drażniące, neurotoksyczne, rakotwórcze itp.) [2].

Zapach panujący w kabinie nowego samochodu wywoływany jest przez mieszaninę różnych związków emitowanych $\mathrm{z}$ materiałów elementów wyposażenia. Lotne związki organiczne (LZO) związane z emisją z wyposażenia wnętrza pojazdu obejmują związki uwalniane z uszczelek, dywaników, detali z tworzyw sztucznych, klejów, farb, skóry oraz pianek służących jako wypełnienie. Innymi źródłami LZO mogą być środki czyszczące, dezodoranty, odświeżacze powietrza, smary, dym papierosowy, a nawet mikroorganizmy [3, 4, 5, 6, 7]. Kabina samochodu stanowi bardzo specyficzne środowisko ze względu na to, iż stosunek ilości materiałów zastosowanych do wykończenia wnętrza do objętości samego wnętrza jest znacznie większy niż $\mathrm{w}$ przeciętnym pomieszczeniu. Ponadto w okresie letnim temperatura we wnętrzu kabiny znacząco wzrasta, prowadząc do zwiększonej dyfuzji LZO i pojawienia się znacznie wyższych stężeń LZO niż w obiektach mieszkalnych. W zależności od elementu wyposażenia również wilgotność może znacząco wpływać na dyfuzję LZO. Ogólnie proces dyfuzji LZO z materiałów wyposażenia samochodu można podzielić na dwa typy. Pierwszy dotyczy rozpuszczalników stosowanych do produkcji polakierowanych detali oraz do produkcji klejów. Związki te uwalniane są bardzo szybko, stąd noszą nazwę związków o emisji kontrolowanej szybkością parowania. Drugi typ może występować w przypadku związków stanowiących dodatki modyfikujące i pozostałości nieprzereagowanych monomerów. W odniesieniu do tych substancji, zwanych związkami o emisji kontrolowanej szybkością dyfuzji, proces dyfuzji zachodzi przez dłuższy czas $[7,8]$.

Informacje na temat rodzaju i stężenia związków chemicznych uwalnianych z materiałów wyposażenia wnętrza samochodu są szczególnie istotne ze względu na ocenę skutków zdrowotnych wynikających z narażenia człowieka na ich działanie, jednak wciąż niewiele wiadomo na temat tego rodzaju zanieczyszczeń. Brown i Cheng wykazali w swojej pracy [9], iż głównymi zanieczyszczeniami występującymi w nowych samochodach są benzen, aceton, etylobenzen, izomery ksylenu, toluen oraz węglowodory. Większość z nich jest toksyczna i potencjalnie szkodliwa dla zdrowia, np. ksyleny stanowią czynniki upośledzające rozwój pło$\mathrm{du}$, aceton powoduje podrażnienie śluzówek, benzen jest znanym czynnikiem rakotwórczym, natomiast etylobenzen został sklasyfikowany przez Międzynarodową Agencję Badań nad Rakiem jako potencjalny czynnik rakotwórczy [11]. Grabbs i wsp. [4] zidentyfikowali we wnętrzu czterech nowych samochodów ponad $60 \mathrm{LZO}$, z całkowitym stężeniem ogólnie przekraczającym stężenie wykryte w otaczającym powietrzu i silnie zmiennym w zależności od badanego samochodu. Jedynie cztery związki zostały wykryte we 
(TVOC) concentrations, excluding formaldehyde, was approximately $14 \mathrm{mg} / \mathrm{m}^{3}$ on the day after delivery, which greatly exceeding the indoor guideline value $(300 \mu \mathrm{g}$ / $\mathrm{m}^{3}$ ), proposed by Seifert [12]. The concentrations of most compounds declined over time, but increased with a rise of interior temperature. These latter conclusions are also contained in Chien report [13]. This study examines interbrand, intra-brand and intra-model variations in VOCs levels inside new cars. Screening tests for VOC from interior parts demonstrated that BHT was the most common present chemical. Long-chain aliphatic hydrocarbons, particularly $\mathrm{C}_{14}-\mathrm{C}_{17}$, toluene, xylenes and process-related compounds, such as plasticizers, were also identified in interior parts.

The current study was carried out with the intent to identify the maximal number of in-vehicle VOCs and asses the air quality in four new cars of the same model, but with different interiors, before they hit the market. Four different solid sorbents (Carbograph 1 TD, Tenax TA, Tenax GR/ Carbopack B and Carbopack C/Carbopack B/ Carbosieve $\mathrm{S}$ III) were applied for the most efficient VOCs adsorption. The air samples were collected on sorbent tubes and analyzed, after thermal desorption, by gas chromatography coupled with mass detector and flame ionization detector (TD-GC-MS/FID).

\section{Methodology}

The vehicles under study included four new cars of the same model but with different interiors (Tab. 1). The examined vehicles were in good operating conditions, the car cabins were free of deodorizers and cigarette smoke, no

wszystkich badanych samochodach: toluen, etylobenzen, ksylen i undekan. Overton i Manura [11] wykonali badania na jednym nowym samochodzie celem wykrycia obecności LZO i zmian zachodzących w ich obrębie wraz z upływem czasu użytkowania samochodu. Przeprowadzone badania pozwoliły na identyfikację ponad $100 \mathrm{LZO}$, w tym wielu prostych i rozgałęzionych węglowodorów, siloksanów, styrenu, podstawionych pochodnych benzenu, butylowanego hydroksytoluenu (BHT), aldehydów i innych. Uzyskane wyniki sugerują, iż emisja LZO w nowym samochodzie obniża się z czasem i jest silnie zależna od temperatury. Z kolei praca Yoshida i Matsunaga [7] donosi o identyfikacji aż 162 związków organicznych pochodzących z wnętrza jednego nowego samochodu. Całkowite stężenie LZO, wyłączając formaldehyd, wyniosło w przybliżeniu $14 \mathrm{mg} / \mathrm{m}^{3}$ po upływie jednego dnia od dostarczenia samochodu, co znacznie przekracza proponowaną przez Seiferta wartość dopuszczalną $\left(300 \mu \mathrm{g} / \mathrm{m}^{3}\right)$ dla całkowitego stężenia LZO w powietrzu wewnętrznym [12]. Stężenia większości związków obniżały się w miarę upływu czasu, ale rosły wraz ze wzrostem temperatury we wnętrzu samochodu. Powyższe wnioski zawarte są również w raporcie Chiena [13]. Raport ten dotyczy badań nad różnicami w poziomach LZO emitowanych wewnątrz pojazdów, występujących pomiędzy poszczególnymi markami samochodów, w obrębie tej samej marki oraz tego samego modelu. Badania przesiewowe dla emisji LZO z wnętrza samochodów wykazały, iż BHT jest najpowszechniej występującym związkiem organicznym. Ponadto zidentyfikowano obecność długołańcuchowych węglowodorów alifatycznych, w szczególności C14-C17, toluenu, ksylenów oraz związków stosowanych jako plastyfikatory.

Badania opisane w tym artykule zostały przeprowadzone $\mathrm{z}$ zamiarem identyfikacji maksymalnej liczby LZO emitowanych z wnętrza samochodu oraz w celu określenia jakości powietrza w czterech nowych samochodach tego samego modelu, ale różniących się wyposażeniem, przed ich wprowadzeniem na rynek. Zastosowano cztery różne adsorbenty stałe (Carbograph 1 TD, Tenax TA, Tenax GR/Carbopack B i Carbopack C/Carbopack B/ Carbosieve S III) w celu zaadsorbowania jak największej liczby LZO. Próbki powietrza pobierano na adsorbenty i analizowano, po wcześniej-

ventilated. All the experiments were conducted at outdoor parking space. Temperature, humidity and pressure inside the cars during sampling process were: $25^{\circ} \mathrm{C}, 40 \% \mathrm{RH}$, $987 \mathrm{hPa}$.

The air samples from each vehicle were collected, separately, on thermal desorption tubes: Carbograph 1TD, Tenax TA, Tenax GR/Carbopack B, and Carbopack C/ Carbopack B/Carbosieve SIII. Application of four different sorbents, with the main role of Carbograph 1TD and Tenax TA, allows the identification of a broad spectrum of organic compounds present in indoor air [14]. For every examined szej desorpcji termicznej, techniką chromatografii gazowej $\mathrm{z}$ detektorem masowym i detektorem płomieniowo-jonizacyjnym (TD-GC-MS/FID).

\section{Metodyka}

Przedmiot badań stanowiły cztery nowe samochody tego samego modelu, ale różniące się wyposażeniem (tab. 1). Testowane samochody były w dobrym stanie technicznym, z kabinami wolnymi od środków odświeżających i dymu papierosowego, niewentylowane. Wszystkie pobory powietrza przeprowadzono na zewnętrznym placu parkingowym. 
car, sampling process was done for 20 minutes with air flow of $100 \mathrm{~mL} / \mathrm{min}$. The sampling of air from each car cabin was performed for all tested sorbents at the same time, by connecting sorbent tubes to the four independent sampling pumps (Gilair 3). Thermal desorption tubes were analyzed using thermal desorption system Unity2 (Markes). Thermal desorption parameters: desorption from tube at $300{ }^{\circ} \mathrm{C}$ for $15 \mathrm{~min}$, cryotrapping at $-30^{\circ} \mathrm{C}$, rapid heat up to $320^{\circ} \mathrm{C}$ at about $60^{\circ} \mathrm{C} / \mathrm{s}$, column pressure $23 \mathrm{psi}$, split ratio $5: 1$. The gas chromatographic system was coupled with flame ionization detector (Agilent 7098A) and a mass spectrometer (Agilent MSD 5975C). Gas chromatograph was equipped with column splitter which allowed sample analysis simultaneously on both, FID and MS, detectors. The capillary column DB$5 \mathrm{~ms}$ UI (60 m x $1 \mu \mathrm{m} \times 0.32 \mathrm{~mm})$ was applied.

Quantitative VOCs analysis was based on calibration curves obtained for toluene (Sigma-Aldrich), based on results from FID detector. Compounds were identified from their mass spectra by using the National Institute of Standards and Technology (NIST08) library. Only compounds with quality score of 80 and above were considered as identified. All chromatographic analysis were performed with use of deuterated toluene (99.6 atom $\% \mathrm{D}$, Sigma-Aldrich) as an internal standard.

\section{Results and discussion}

Four vehicles interiors were sampled over the course of this study. In case of each examined vehicle, four different sorbents (Carbograph 1 TD, Tenax TA, Tenax GR/Carbopack B and Carbopack C/Carbopack B/ Carbosieve S III) were applied to detect and identify the maximal number of VOCs from the car-cabins. Comparison of the number of VOCs identified in analyzed vehicles 1-4 (with quality score of 80 and above) is presented in Figure 1. The results showed that number of identified compounds was similar for cars 1 and 4 (152 and 154 compounds, respectively), slightly lower for car 3 (144 compounds) and noticeably higher for car 2 (192 identified compounds).
Podczas poboru próbek w kabinach samochodów panowały następujące warunki temperatury, wilgotności i ciśnienia atmosferycznego: $25{ }^{\circ} \mathrm{C}, 40 \%$ wilgotności względnej i $987 \mathrm{hPa}$.

Próbki powietrza z wnętrza każdego samochodu były pobierane osobno na rurki wypełnione adsorbentami: Carbograph 1TD, Tenax TA, Tenax GR/Carbopack B, i Carbopack C/Carbopack B/Carbosieve SIII. Zastosowanie czterech różnych adsorbentów, z głównym udziałem Carbograph 1 TD oraz Tenax TA, pozwoliło na identyfikację szerokiego spektrum związków organicznych obecnych w powietrzu wewnątrz kabiny samochodu [14]. Dla każdego badanego samochodu próbki powietrza były pobierane przez 20 minut z przepływem $100 \mathrm{~mL} / \mathrm{min}$. Proces poboru powietrza $\mathrm{z}$ każdej kabiny samochodowej odbywał się dla wszystkich adsorbentów w tym samym czasie, $\mathrm{z}$ wykorzystaniem czterech niezależnych pompek (Gilair 3). Adsorbenty z pobranymi próbkami powietrza poddano desorpcji termicznej $\mathrm{z}$ wykorzystaniem termodesorbera Unity2 (Markes). Podczas procesu desorpcji panowały następujące warunki: temperatura desorpcji $300{ }^{\circ} \mathrm{C}$ przez 15 min, następnie uwolnione związki zatrzymywane były na pułapce wymrażającej o temperaturze $-30{ }^{\circ} \mathrm{C}$ i gwałtownie ogrzewane do temperatury $320^{\circ} \mathrm{C} \mathrm{z}$ szybkością ok. $60{ }^{\circ} \mathrm{C} / \mathrm{s}$, ciśnienie na kolumnie chromatograficznej wynosiło 23 psi, split 5:1. Stosowany układ chromatograficzny wyposażony był w detektor płomieniowo-jonizacyjny (Agilent 7098A) oraz detektor masowy (Agilent MSD 5975C). Zastosowano splitter (dzielnik strumienia gazów) pozwalający na jednoczesną analizę z wykorzystaniem obydwu detektorów, FID oraz MS. Wykorzystano kapilarną kolumnę DB-5ms UI (60 $\mathrm{m}$ x $1 \mu \mathrm{m}$ x 0,32 mm).

Analizę ilościową LZO przeprowadzono, opierając się na krzywych kalibracyjnych uzyskanych dla wzorca toluenu (Sigma-Aldrich), dla wyników uzyskanych przy zastosowaniu detektora FID. Identyfikacja związków odbyła się na podstawie ich spektrogramów masowych z zastosowaniem biblioteki widm masowych NIST08. Za zidentyfikowane uznano wyłącznie związki $\mathrm{z}$ dopasowaniem do bazy NIST08 z prawdopodobieństwem nie mniejszym niż $80 \%$. Wszystkie analizy chromatograficzne prowadzono w obecności deuterowanego toluenu (99,6 atom \%D, SigmaAldrich) jako wzorca wewnętrznego.

\section{Wyniki i dyskusja}

Badania opisane w niniejszej pracy obję- 


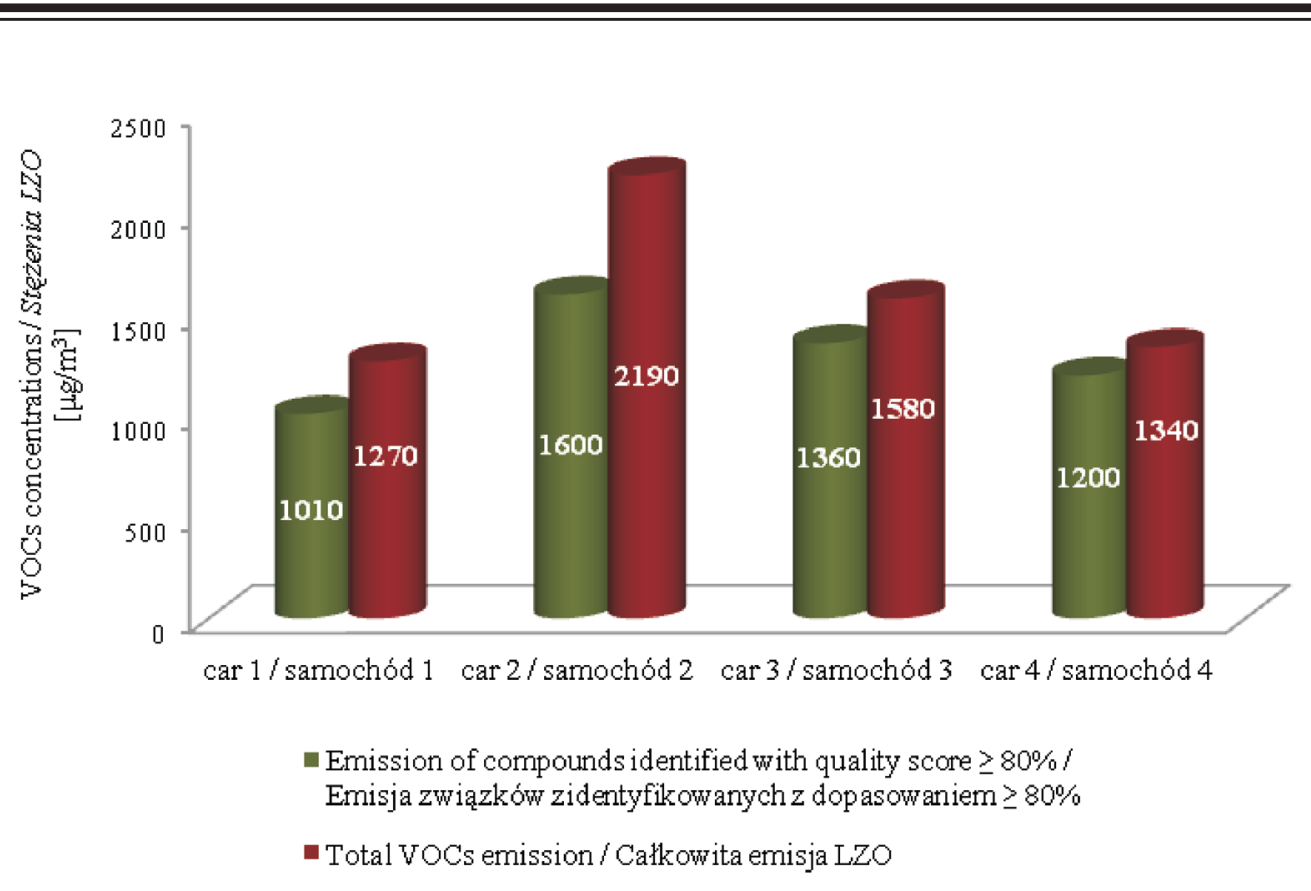

Fig. 2. Concentrations of VOCs identified in tested cars $1-4$ Rys. 2. Stężenia LZO zidentyfikowanych $w$ badanych samochodach $1-4$ ły pobory powietrza z wnętrza czterech samochodów. Dla wszystkich badanych samochodów do wykrycia i identyfikacji maksymalnej liczby LZO występujących w kabinach samochodowych zastosowano cztery różne adsorbenty (Carbograph 1 TD, Tenax TA, Tenax GR/Carbopack B i Carbopack C/Carbopack B/ Carbosieve S III). Porównanie liczby zidentyfikowanych LZO (z dopasowaniem do bazy NIST08 z prawdopodobieństwem $\geq$ $80 \%$ ) w badanych samochodach $1-4$ przedstawiono na

Figure 2 presents the concentrations of VOCs identified in four tested vehicles, by application of all sorbents. The results of quantitative VOCs analysis were based on calibration curves prepared for individual sorbents used in this study. Determination of TVOC emission was performed with application of sorbent Carbograph $1 \mathrm{TD}$, selected previously as a most relevant sorbent for detection of VOCs from car interior [14]. The estimated VOCs level for air sample collected from cabin of car 1 was $1010 \mu \mathrm{g} / \mathrm{m}^{3}$ (79\% of TVOC emission), car $2-1600 \mu \mathrm{g} / \mathrm{m}^{3}$ (73\% of TVOC emission), car $3-1360 \mu \mathrm{g} / \mathrm{m}^{3}$ (87\% of TVOC emission) and for car $4-1200 \mu \mathrm{g} / \mathrm{m}^{3}$ (89\% of TVOC emission). In each case, the interior TVOC concentrations exceeded the indoor guideline values proposed by Seifert [12]. The other finding was that the highest value of VOCs emission for air sample from car 2 , is correlated with the greatest number of identified compounds in case of this vehicle.

Figure 3 presents the percent contribution of main groups of organic compounds in number of VOCs identified in tested cars 1-4. In all examined vehicles, alkanes were the main class of chemicals occurring in car-cabins interior $(20-25 \%)$. High number of cycloalkanes $(16-20 \%)$, aromatic hydrocarbons $(15-21 \%)$ and compounds marked as others $(14-24 \%)$ was also noticed. The share below $10 \%$ was observed for group consisting of alcohols, ethers, esters $(8-10 \%)$ and aldehydes with ketones $(4-8 \%)$. Terpenes $(1-2 \%)$ were the least frequently represented class of identified VOCs. Presented data indicate, that there was no significant differences in contribution of main classes of organic compounds in number of identified VOCs, between examined vehicles. However, some important differences might appear in case of individual compound share in each groups of organic compounds. rys. 1. Uzyskane wyniki wykazały, że liczba zidentyfikowanych związków była podobna dla samochodów 1 i 4 (odpowiednio 152 i 154 związki), nieco niższa dla samochodu 3 (114 związki) i znacząco wyższa dla samochodu 2 (192 zidentyfikowane związki).

Na rysunku 2 przedstawiono stężenia LZO zidentyfikowanych w czterech badanych samochodach, przy zastosowaniu wszystkich adsorbentów. Wyniki ilościowej analizy LZO uzyskano, opierając się na krzywych kalibracyjnych przygotowanych dla poszczególnych adsorbentów użytych w badaniach. Oznaczenie całkowitej emisji LZO przeprowadzono z wykorzystaniem adsorbentu Carbograph 1 TD, wybranego uprzednio jako najbardziej uniwersalny adsorbent do detekcji LZO z wnętrza samochodów [14]. Poziom LZO zidentyfikowanych $\mathrm{w}$ próbce powietrza pobranej $\mathrm{z}$ kabiny samochodu 1 wyniósł $1010 \mu \mathrm{g} / \mathrm{m}^{3}$ (79\% całkowitej emisji LZO), z kabiny samochodu $2-1600 \mu \mathrm{g} / \mathrm{m}^{3}(73 \%$ całkowitej emisji LZO), dla samochodu $3-1360 \mu \mathrm{g} / \mathrm{m}^{3}$ (87\% całkowitej emisji LZO) i dla samochodu $4-1200 \mu \mathrm{g} /$ $\mathrm{m}^{3}$ (89\% całkowitej emisji LZO). We wszystkich badanych samochodach całkowita emisja LZO przekroczyła proponowane przez Seiferta dopuszczalne wartości stężeń LZO [12]. Ponadto zaobserwowano, że najwyższa emisja LZO w przypadku próbki powietrza z samochodu 2 skorelowana jest z największą liczbą zidentyfikowanych związków uzyskaną dla tego samochodu.

Na rysunku 3 przedstawiono procentowy udział głównych klas związków organicznych w liczbie LZO zidentyfikowanych w badanych samochodach $1-4$. We wszystkich przypadkach alkany stanowiły główną klasę związków organicznych występujących wewnątrz kabin samochodowych $(20-25 \%)$. Zaobserwowano również obecność dużej liczby 


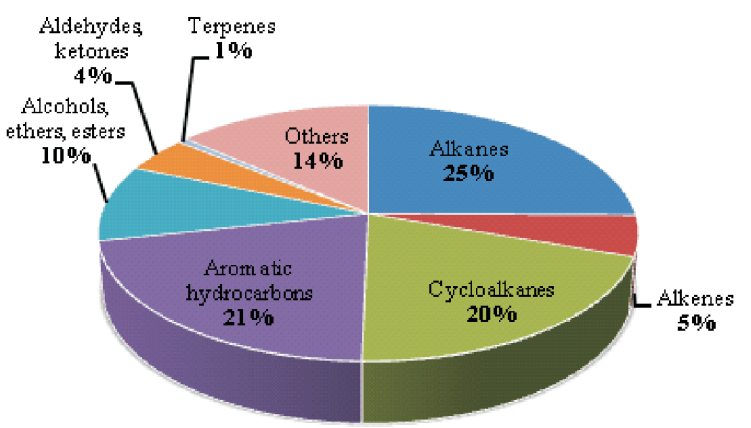

car 1 / samochóll

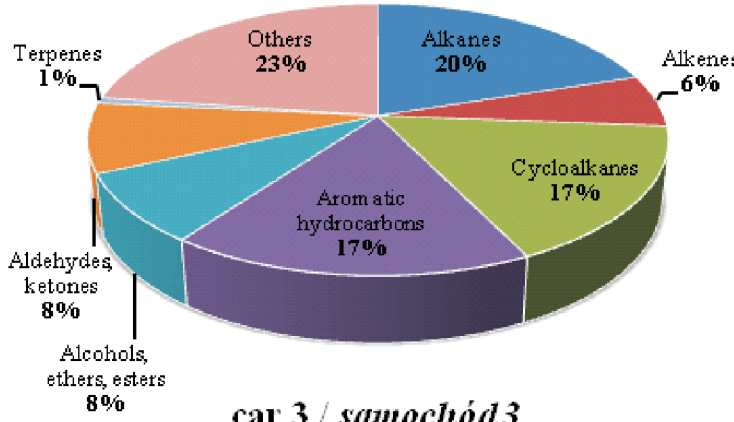

car $3 /$ satutochód 3

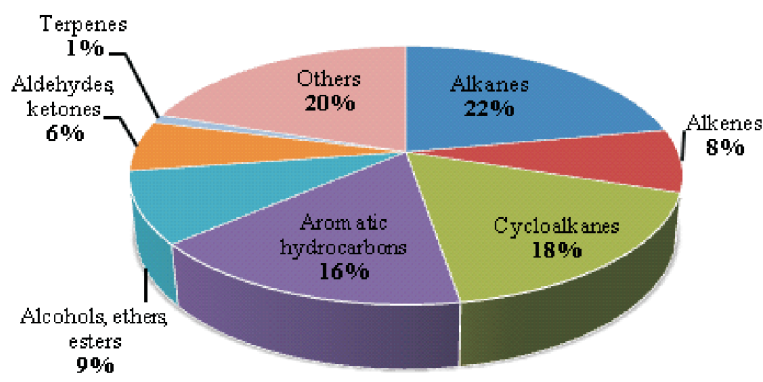

car $2 /$ samochód 2

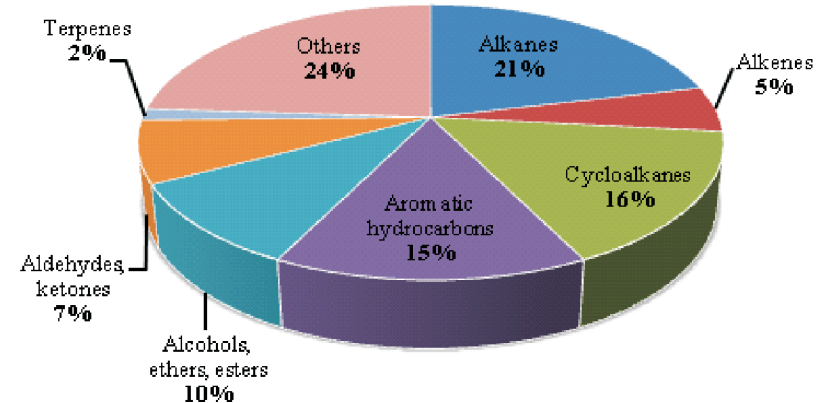

car 4 / samochóól4

Fig. 3. The percent contribution of main groups of organic compounds in number of VOCs identified in tested cars $1-4$

Rys. 3. Procentowy udziat poszczególnych klas związków organicznych w liczbie LZO zidentyfikowanych w badanych samochodach 1 - 4

Aromatic hydrocarbons are a group of compounds containing a number of VOCs particulary harmful to human health, therefore detailed analysis of this class of chemicals was performed. Comparisons of aromatic hydrocarbons concentrations, depending on tested vehicle, are presented in Figure 4 and 5 (two graphs due to significant differences in aromatic VOCs emission). Presented results include only those compounds that were detected in at least two of four tested vehicles. Our data pointed out that the main aromatic air pollutants, occuring inside car cabins, were xylene isomers $\left(8-123 \mu \mathrm{g} / \mathrm{m}^{3}\right)$, toluene $\left(10-56 \mu \mathrm{g} / \mathrm{m}^{3}\right)$, benzoic acid $\left(33-45 \mu \mathrm{g} / \mathrm{m}^{3}\right)$, ethylbenzene $\left(15-45 \mu \mathrm{g} / \mathrm{m}^{3}\right)$ and trimethylbenzene $\left(9-23 \mu \mathrm{g} / \mathrm{m}^{3}\right)$. High concentrations of toluene, ethylbenzene and xylenes are correlated, because these solvents are originally used as mixture and none of single compound reaches a high level in car-cabin air [8]. The highest concentrations of aromatic VOCs, including mentioned above, was observed for car 2. In case of other tested cars (1, 3 and 4), the concentrations of most aromatic VOCs were much lower. Obtained results demonstrated, for car 3 and 4, remarkable similarities in distribution of individual aromatic VOC concentrations. These resemblances probably occurred due to the vehicles interior - car 3 and 4 were equipped with identical checkered fabric material with likely similar cykloalkanów (16 - 20\%), węglowodorów aromatycznych $(15-21 \%)$ i związków z grupy oznaczonej jako inne (14 $24 \%$ ). Poziom poniżej $10 \%$ zaobserwowano w przypadku grupy składającej się z alkoholi, eterów i estrów $(8-10 \%)$ oraz dla aldehydów i ketonów (4-8\%). Najmniej licznie reprezentowaną klasę zidentyfikowanych LZO stanowiły terpeny $(1-2 \%)$. Przedstawione wyniki wykazują, iż pomiędzy badanymi samochodami nie występują znaczące różnice w udziale głównych klas związków organicznych w liczbie zidentyfikowanych LZO. Jednakże istotne różnice mogą pojawić się na etapie rozpatrywania udziału pojedynczych składników występujących w poszczególnych klasach związków organicznych.

Węglowodory aromatyczne stanowią grupę związków zawierających liczne LZO szczególnie szkodliwe dla ludzkiego zdrowia, wobec czego przeprowadzono szczegółową analizę tej klasy związków organicznych. Porównanie stężeń węglowodorów aromatycznych, w zależności od badanego samochodu, przedstawiono na rys. 4 i 5 (prezentacja dwóch wykresów spowodowana znacznymi różnicami w emisji aromatycznych LZO). Przedstawione wyniki obejmują tylko te związki, których obecność stwierdzono w co najmniej dwóch z czterech testowanych samochodów. Głównymi aromatycznymi zanieczyszczeniami powietrza wewnątrz kabin samochodowych są izomery ksylenów 


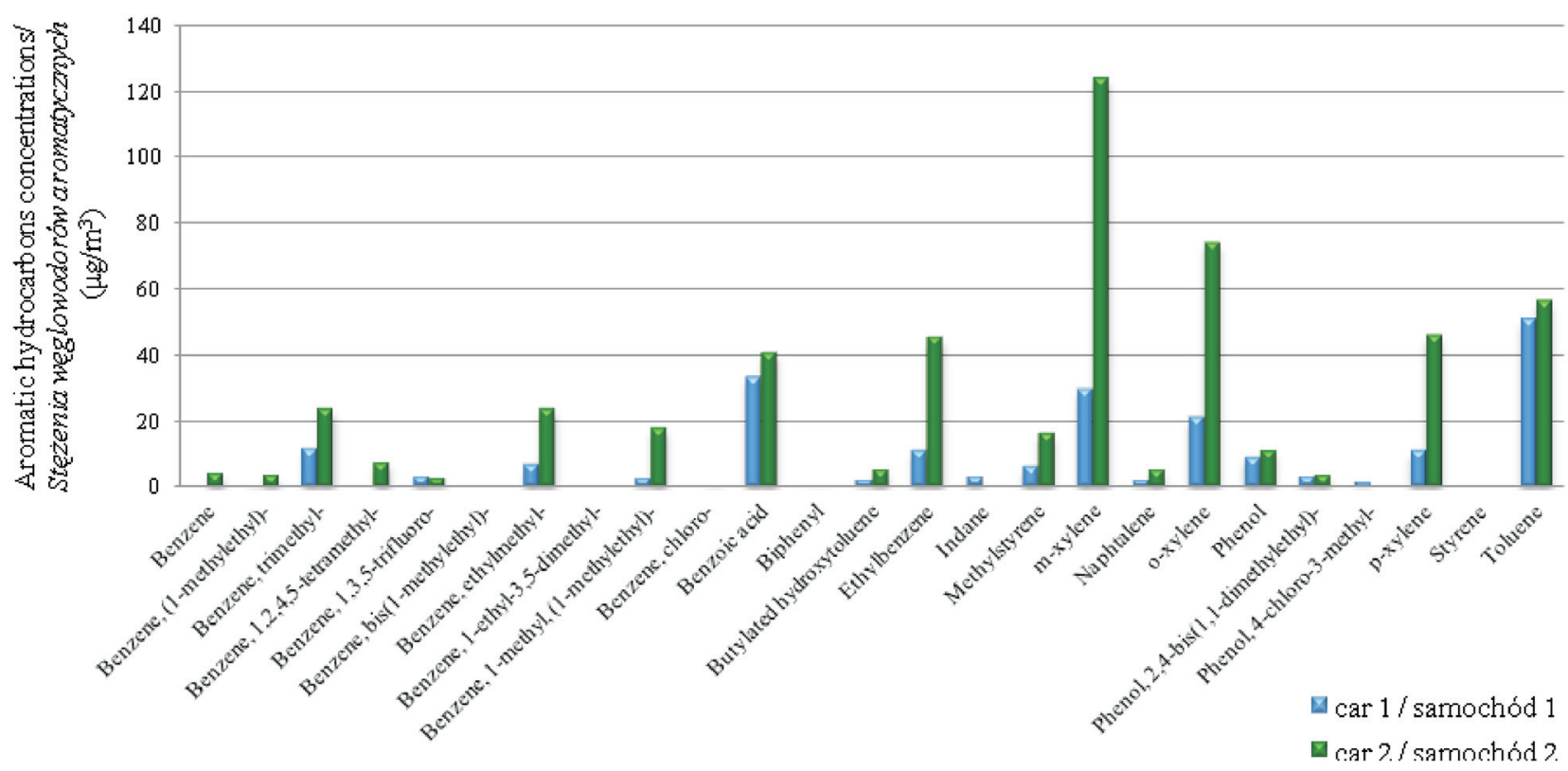

Fig. 4. Comparision of concentrations of aromatic hydrocarbons identified in cars 1 and 2

Rys. 4. Porównanie steżeń węglowodorów aromatycznych zidentyfikowanych $w$ samochodach 1 i 2

VOCs emission, but different than in case of car 1 and 2, equipped in black fabric upholstery.

All VOCs, identified in case of four tested cars, were compared in order to find repeated compounds (Fig. 6). The number of 330 chemicals were presented in cabins of at least one examined vehicle, 169 VOCs - in at least two tested cars, 88 - in at least three tested cars and, finally, 54 organic compounds were identified in all examined vehicles. List of classified VOCs occuring in cabins of all tested car is presented in Table 2 . $\left(8-123 \mu \mathrm{g} / \mathrm{m}^{3}\right)$, toluen $\left(10-56 \mu \mathrm{g} / \mathrm{m}^{3}\right)$, kwas benzoesowy $\left(33-45 \mu \mathrm{g} / \mathrm{m}^{3}\right)$, etylobenzen $\left(15-45 \mu \mathrm{g} / \mathrm{m}^{3}\right)$ i trimetylobenzen $\left(9-23 \mu \mathrm{g} / \mathrm{m}^{3}\right)$. Wysokie stężenia toluenu, etylobenzenu i ksylenów są ze sobą powiązane, ponieważ rozpuszczalniki te używane są w mieszaninie i jako pojedyncze składniki nigdy nie osiągną wysokiego poziomu emisji w powietrzu z wnętrza samochodów [8]. Najwyższe stężenia aromatycznych LZO, w tym omawianych powyżej, zaobserwowano dla samochodu 2. Dla pozostałych badanych samochodów (1, 3 i 4) stężenia większości aromatycznych

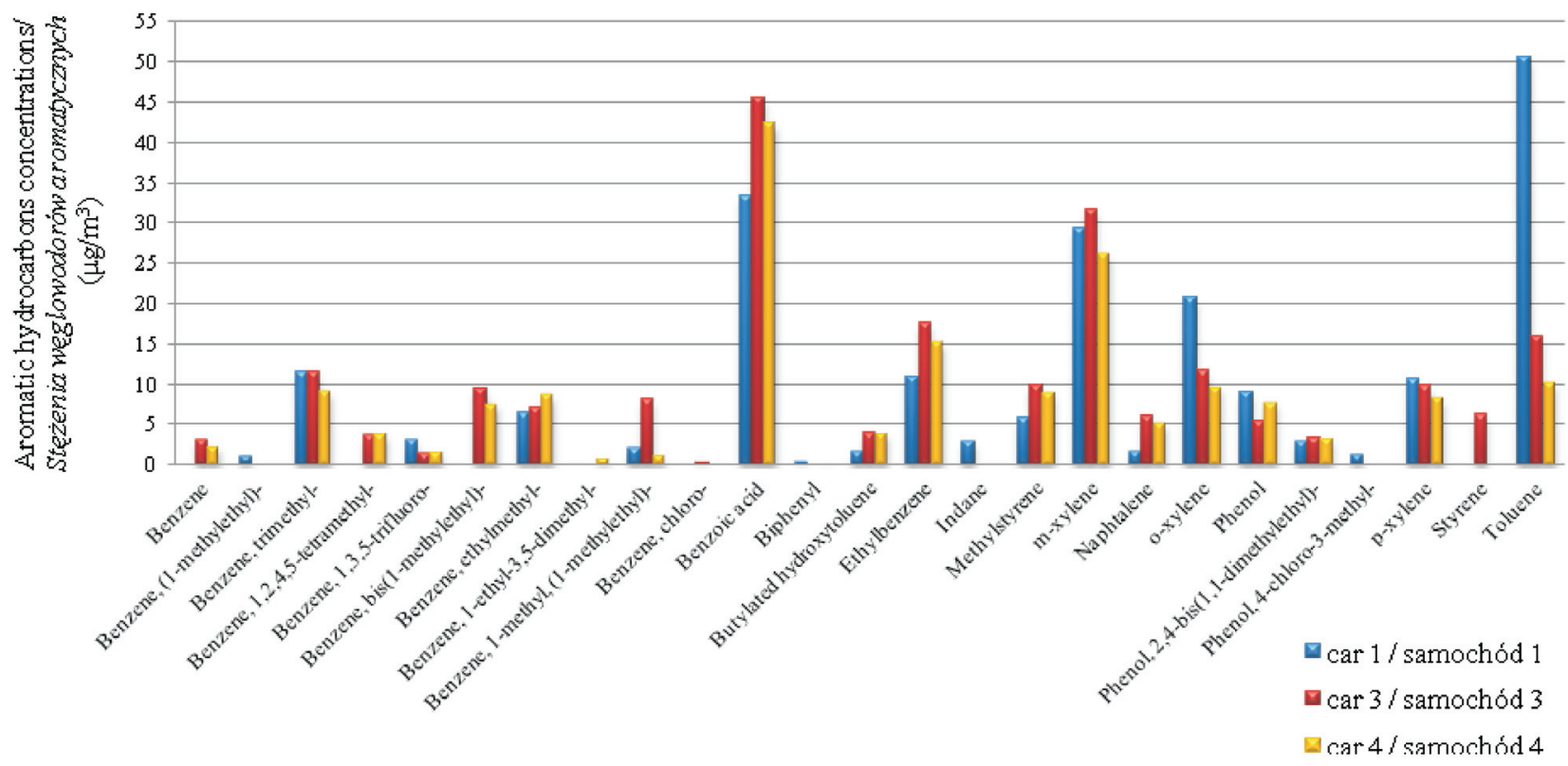

Fig. 5. Comparision of concentrations of aromatic hydrocarbons identified in cars 1, 3 and 4

Rys. 5. Porównanie stężén węglowodorów aromatycznych zidentyfikowanych $w$ samochodach 1, 3 i 4 


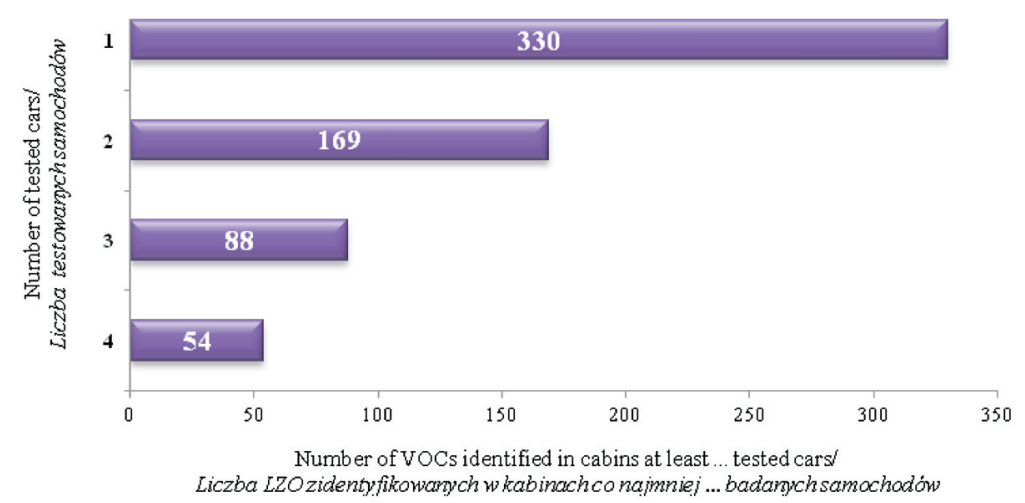

Fig. 6. Comparision of number of VOCs repeated in cabis of tested cars $1-4$

Ry . 6. Porównanie liczby LZO powtarzających się w kabinach badanych samochodów $1-4$

On the basis of results from Table 2, the main air pollutants identified in all car cabins were compounds from class of alkanes and aromatic hydrocarbons. The other group of organic compounds were cycloalkanes, alcohols with phenols, esters and aldehydes. One alkene, one ketone and number of others unclassified compounds were also identified.

Table 2. List of VOCs occurring in cabins of all examined vehicles

Tabela 2. Wykaz LZO występujacych w kabinach wszystkich badanych samochodów

\begin{tabular}{|c|c|}
\hline \multicolumn{2}{|c|}{ Compound name/nazwa związku } \\
\hline $\begin{array}{l}\text { Alkanes/alkany } \\
\text { Heptane, 2,4-dimethyl- } \\
\text { Decane } \\
\text { Decane, 2-methyl- } \\
\text { Decane, 3-methyl- } \\
\text { Decane, 4-methyl- } \\
\text { Undecane } \\
\text { Undecane, 2-methyl- } \\
\text { Undecane, 4-methyl- } \\
\text { Undecane, 3,6-dimethyl- } \\
\text { Dodecane } \\
\text { Tridecane } \\
\text { Tetradecane } \\
\text { Cycloalkanes/cykloalkany } \\
\text { Cyclohexane } \\
\text { Cyclohexane, methyl- } \\
\text { Cyclohexane, isothiocyanato- } \\
\text { Cyclododecane } \\
\text { cis-decalin, 2-syn-methyl- } \\
\text { Naphthalene, decahydro-, trans- } \\
\text { Alkenes/alkeny } \\
\text { 1-dodecene } \\
\text { Aromatic hydrocarbons/weglowodory aroma- } \\
\text { tyczne } \\
\text { Octane, 4-methyl- } \\
\text { Benzene } \\
\text { Benzene, 1,3,5-trifluoro- } \\
\text { Benzene, 1,2,3-trimethyl- } \\
\text { Benzene, 1,3,5-trimethyl- } \\
\text { Benzene, 1,2,4,5-tetramethyl- } \\
\text { Benzene, 1-methyl-3-(1-methylethyl)- } \\
\text { Benzene, 1-ethyl-3-methyl- } \\
\text { ald }\end{array}$ & $\begin{array}{l}\text { Butylated hydroxytoluene } \\
\text { Ethylbenzene } \\
\text { Xylenes (isomers) } \\
\text { Toluene } \\
\text { Methylstyrene } \\
\text { Alcohols and phenols/alkohole i fenole } \\
\text { 1-butanol } \\
\text { Phenol } \\
\text { Phenol, 2,4-bis(1,1-dimethylethyl)- } \\
\text { Aldehydes/aldehydy } \\
\text { Benzaldehyde } \\
\text { Furfural } \\
\text { Ketones/ketony } \\
\text { Phenyl methyl ketone } \\
\text { Esters/estry } \\
\text { Diethyl phthalate } \\
\text { Ethyl acetate } \\
\text { 2-butoxyethyl acetate } \\
\text { Others/inne } \\
\text { 1(3h)-isobenzofuranone } \\
\text { Acetic acid } \\
\text { Benzoic acid } \\
\text { Bicyclo[2.2.1]hept-2-ene,5-ethylidene- } \\
\text { Butyrolactone } \\
\text { Cyclodecene, 1-methyl- } \\
\text { Phenylmaleic anhydride } \\
\text { Phthalic anhydride } \\
\text { Silane, dimethoxydimethyl- } \\
\text { Silanol, trimethyl- }\end{array}$ \\
\hline
\end{tabular}

LZO wykazały znacznie niższy poziom. W odniesieniu do samochodów 3 i 4 uzyskane wyniki wykazały istotne podobieństwa $\mathrm{w}$ zakresie rozkładu stężeń poszczególnych aromatycznych LZO. Podobieństwa te prawdopodobnie wynikają z wyposażenia wnętrza samochodów - samochód 3 i 4 wyposażone były w identyczną tapicerkę $\mathrm{z}$ materiału $\mathrm{w}$ kratkę, najprawdopodobniej z podobną emisją LZO, odmienną od emisji występującej dla samochodów 1 i 2 wyposażonych w tapicerkę z czarnej tkaniny.

Wszystkie LZO zidentyfikowane dla próbek powierza z czterech badanych samochodów zostały porównane celem znalezienia powtarzających się związków (rys. 6). Wyodrębniono 330 związków obecnych w co najmniej jednym z badanych samochodów, 169 LZO - dla co najmniej dwóch samochodów, 88 - dla co najmniej trzech badanych samochodów, natomiast we wszystkich samochodach zidentyfikowano obecność 54 związków organicznych. Wykaz LZO występujących w kabinach wszystkich badanych samochodów z podziałem na grupy przedstawiono $\mathrm{w}$ tabeli 2.

Na podstawie wyników zamieszczonych w tabeli 2 można stwierdzić, że głównymi zanieczyszczeniami powietrza zidentyfikowanymi we wszystkich kabinach samochodowych były związki z grupy alkanów i węglowodorów aromatycznych. Ponadto oznaczono związki należące do grup cykloalkanów, alkoholi i fenoli, estrów oraz aldehydów. Wykryto również obecność jednego alkenu, jednego ketonu i wiele innych, niesklasyfikowanych związków organicznych.

Elementy wyposażenia wnętrza samochodu, takie jak plastikowe detale, tapicerka, dywaniki, kleje, smary i inne stanowią główne źródło LZO występujących wewnątrz kabin nowych samochodów. Alkany, zwłaszcza długołańcuchowe węglowodory alifatyczne $\left(\mathrm{C}_{14}-\mathrm{C}_{17}\right)$, emitowane są ze smarów używanych do smarowania cześci mechanicznych, takich jak szyny siedzeń [4]. Siloksany mogą pochodzić z preparatów służących do czyszczenia i smarowania [11], a także z pianki poliuretanowej, gdzie służą jako stabilizatory. Kleje stosowane przy produkcji różnych części wewnętrznych są prawdopodobnie głównym źródłem takich związków, jak: tolu- 
Interior components, such as plastic moldings, upholstery, carpeting, adhesives, lubricants and others, are the main sources of VOCs occuring in air of new car cabins. Alkanes, especially long-chain aliphatic hydrocarbons $\left(\mathrm{C}_{14}-\mathrm{C}_{17}\right.$ hydrocarbons $)$ are emitted from the greases that are used to lubricate mechanical parts such as seat rails [4]. Siloxanes may be derived from cleaning and lubricating products [11], also from polyurethane foam, where serve as foam stabilizers. Adhesives, that are applied to manufacture various interior parts, are probably the main source of toluene, xylenes, trimethylbenzenes, naphtalenes and number of other chemicals detected inside the cabins [13]. Styrene emission may be associated with off-gassing from new carpets (emission from styrene-butadiene-rubber latex) or from plastic components of the vehicle interiors [4, 11]. Carpets (also carpet cushions), varnishes, paints and adhesives based on epoxy resins are potential sources of phenolic compounds. Moreover, carpets with styrene-butadienerubber and polyurethane backings or textile backing, but with styrene-butadiene latex precoat are the sources of halogenated aromatic compounds (e.g. trifluorobenzenes) [15]. Butylated hydroxytoluene (BHT) is a common anti-oxidant applied in leather, synthetic rubber and plastic treatments $[11,13]$. Phtalates are used mainly as plasticizers for vinyl resins or plastics, moreover these compounds are presented in adhesives (mainly polychlorobutadiene) used to manufacture interior parts [13]. Acetic acid emission is associated with application of paints, coatings, adhesives, for example products based on polyvinyl acetate, acid-cured silicone and cleaning agents [16]. Benzoic acid is a compound used in the production of plasticizers in adhesive formulations; it is also used to improve the properties of alkyd resins for paints and coatings and as a rubber polymerization retarder [17].

\section{Conclusions}

The aim of this work was to perform possibly complete identification and quantitative determination of VOCs from the interior of four new cars. Application of four different-type sorbents allows to detect broad spectrum of organic compounds - the total number of 330 VOCs were identified in the interior air of tested cars. Obtained data showed high VOCs concentrations, in all cases exceeded the indoor guideline values. Alkanes, aromatic hydrocarbons and cycloalkanes were found to be the classes with major contribution in total VOC emission. Detailed analysis of aromatic hydrocarbons group revealed xylene isomers, toluene, benzoic acid, ethylbenzene and trimethylbenzene as the main aromatic air pollutants.

Presented results shows that new car's users are exposed to a wide variety of potentially harmful VOCs, emitted from interior components. Improving the air quality area in the car-cabins is particularly important for the reduction of VOCs emission, by finding possible sources of contaminations (proper components) and eliminating them from vehicle interior. en, ksyleny, trimetylobenzeny, naftaleny i wielu innych związków wykrytych wewnątrz kabin samochodów [13]. Emisja styrenu może być związana z uwalnianiem tego związku z nowych dywaników (emisja z lateksu styrenowo-butadienowego) lub elementów wyposażenia samochodu wykonanych z tworzyw sztucznych $[4,11]$. Dywaniki (w tym materiały wygłuszające), farby, lakiery i kleje epoksydowe są potencjalnymi źródłami związków fenolowych. Ponadto styrenowo-butadienowe dywaniki gumowe, dywaniki poliuretanowe i tekstylne, ale pokryte powłoką z lateksu styrenowo-butadienowego, stanowią źródło halogenowanych związków organicznych (np. trifluorobenzenów) [15]. Butylowany hydroksytoluen (BHT) jest powszechnym antyoksydantem stosowanym przy produkcji skóry, gumy syntetycznej i tworzyw sztucznych $[11,13]$. Ftalany używane są głównie jako plastyfikatory przy produkcji żywic winylowych oraz tworzyw sztucznych, ponadto związki te są obecne w klejach (głównie w kleju polichlorobutadienowym) stosowanych przy produkcji elementów wyposażenia [13]. Emisja kwasu octowego może pochodzić od farb, lakierów, klejów, np. produktów na bazie octanu poliwinylowego, uszczelniaczy silikonowych utwardzanych kwasem i środków czyszczących [16]. Kwas benzoesowy jest związkiem wykorzystywanym do produkcji plastyfikatorów stosowanych do wytwarzania preparatów adhezyjnych; używany jest ponadto do poprawy właściwości żywic alkidowych stosowanych do wytwarzania farb i powłok kryjących oraz jako spowalniacz procesu polimeryzacji tworzyw gumowych [17].

\section{Wnioski}

Celem niniejszej pracy było przedstawienie przeprowadzonej jak najbardziej kompletnej identyfikacji LZO i wyznaczenie stężeń związków organicznych występujących we wnętrzu czterech nowych samochodów. Zastosowanie czterech różnych adsorbentów pozwoliło na wykrycie szerokiego spektrum związków - we wnętrzu badanych samochodów zidentyfikowano całkowitą liczę 330 LZO. Uzyskane wyniki wykazały wysokie stężenia LZO, we wszystkich przypadkach przekraczające dopuszczalne wartości dla powietrza wewnętrznego. Stwierdzono, iż alkany, węglowodory aromatyczne i cykloalkany mają największy udział w całkowitej emisji LZO. Szczegółowa analiza grupy obejmującej węglowodory aromatyczne wykazała, iż głównymi aromatycznymi zanieczyszczeniami powietrza są: izomery ksylenu, toluen, kwas benzoesowy, etylobenzen oraz trimetylobenzen.

Przedstawione wyniki wykazały, iż użytkownicy nowych samochodów narażeni są na działanie licznych potencjalnie szkodliwych LZO emitowanych z wyposażenia wnętrza samochodu. Poprawa jakości powietrza w kabinie samochodowej jest szczególnie istotna $\mathrm{z}$ punktu widzenia obniżenia emisji LZO, co można zrealizować przez zidentyfikowanie możliwych źródeł zanieczyszczeń (odpowiedni element wyposażenia) i wyeliminowanie ich z wnętrza samochodu. 


\section{Acknowledgements}

This work was supported by Polish Ministry of Science and Higher Education (project No. N509 480438).

\section{Podziękowania}

Badania zostały wykonane w ramach projektu rozwojowego finansowanego przez Ministerstwo Nauki i Szkolnictwa Wyższego (projekt Nr N509 480438).

Paper reviewed/Artykut recenzowany

\section{Bibliography/Literatura}

[1] ECA-IAQ (European Collaborative Action "Indoor Air Quality and its Impact on Man"), Total Volatile Organic Compounds (TVOC) in Indoor Air Quality Investigations. Report No 19, EUR 17675 EN. Luxembourg: Office for Official Publications of the European Communities 1997.

[2] WHO (World Health Organisation), Indoor air quality: organic pollutants. Euro Reports and Studies No. 111. Copenhagen: World Health Organization, Regional Office for Europe 1989.

[3] Fedoruk M.J., Kerger B.D.: Measurement of volatile organic compounds inside automobiles. J Environ Eng 2003, 13, p. $31-41$.

[4] Grabbs J.S., Corsi R.L., Torres V.M.: Volatile organic compounds in new automobiles: screening assessment. J Environ Eng 2000, 126 (10), p. 974-977.

[5] Yo W.K., Yu C.H.: Public bus and taxicab drivers work-time exposure to aromatic volatile organic compounds. Environ Res 2000, 86 (1), p. 66-72.

[6] Rose L.J., Simmons R.B., Crow S.A., Ahearn D.G.: Volatile organic compounds associated with microbial growth in automobile air conditioning systems. Curr Microbiol 2000, 41, p. 206-209.

[7] Yoshida T., Matsunaga I.: A case study on identification of airborne organic compounds and time courses of their concentrations in the cabin of a new car for private use. Environ Int 2006, 32 (1), p. 58-79.

[8] Sato S.: Air-Quality in Auto-Cabin. R\&D Review of Toyota CRDL 2004, 39, p. 36-43.
[9] Brown S.K., Cheng M.: Volatile organic compounds (VOCs) in new car interiors. 15th International Clean Air \& Environment Conference. Sydney, CASANZ, 2000, p. 464-46.

[10] International Agency for Research on Cancer (IARC), Group 2B: possibly carcinogenic to humans, 2000.

[11] Overton S.V., Manura J.J.: Identification of volatile organic compounds in a new automobile. SIS Application Note 36a, Scientific Instrument Services 1999.

[12] Seifert B.: Volatile organic compounds. In: Maroni M, Seifert $\mathrm{B}$, Lindvall T, editors. Indoor air quality. A comprehensive reference book. Air quality monographs, vol. 3. Netherlands: Elsevier Science 1995, p. 819-822.

[13] Chien Y.C.: Variations in amounts and potential sources of volatile organic chemicals in new cars. Sci Total Environ 2007, 383 , p. 228-239.

[14] Gołda-Kopek A., Faber J., Łomankiewicz D., Brodzik K., Nowak J., Świątek A.: Identification of in-vehicle volatile organic compounds by adsorption/thermal desorption-GC/MS. Proceedings of Air Quality-Science and Application, Athens, Greece 2012.

[15] Sollinger S., Levsen K.: Indoor pollution by organic emissions from textile floor coverings: climate test chamber studies under static conditions. Atmos Environ 1994, 28 (14), p. 2369 2378.

[16] Organic Indoor Air Pollutants: Occurrence, Measurement, Evaluation. 2nd edition, WILEY-VCH 2009.

[17] IPCS (International Programme on Chemical Safety), Benzoic acid and sodium benzoate. Concise International Chemical Assessment Document No 26, Geneva: World Health Organization 2000.
Anna Gołda-Kopek, PhD. - research-technical specialist, BOSMAL Automotive Research and Development Institute Ltd in Bielsko-Biała.

Dr Anna Golda-Kopek-specjalista badawczo-techniczny w Zaktadzie Materiałoznawstwa, Instytut Badań i Rozwoju Motoryzacji BOSMAL Sp. z o.o., Bielsko-Biała. e-mail: anna.golda-kopek@bosmal.com.pl

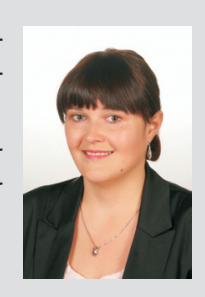

Damian Łomankiewicz, MSc. - chemical laboratory manager, BOSMAL Automotive Research and Development Institute Ltd in Bielsko-Biała.

Mgr Damian Lomankiewicz - kierownik Pracowni Chemicznej, Zakład Materiałoznawstwa, Instytut Badań i Rozwoju Motoryzacji BOSMAL Sp. z o.o., Bielsko-Biała. e-mail: damian.lomankiewicz@bosmal.com.pl

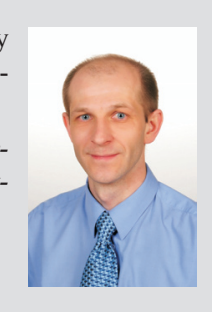

Joanna Faber, MEng. - research specialist, BOSMAL Automotive Research and Development Institute Ltd in Bielsko-Biała.

Mgr inż. Joanna Faber-specjalista ds. badań w Zakładzie Materiałoznawstwa, Instytut Badań i Rozwoju Motoryzacji BOSMAL SP. z o.o., Bielsko-Biała. e-mail: joanna.faber@bosmal.com.pl

Krzysztof Brodzik, DEng. - research-technical specialist, BOSMAL Automotive Research and Development Institute Ltd in Bielsko-Biała.

Dr inż. Krzysztof Brodzik - specjalista badawczo-techniczny w Zakładzie Materiałoznawstwa, Instytut Badań $i$ Rozwoju Motoryzacji BOSMAL Sp. z o.o., Bielsko-Biała. e-mail: krzysztof.brodzik@bosmal.com.pl 